\title{
Weldability and weld joint failures
}

\author{
M N CHANDRASEKHARAIAH \\ Welding Research Institute, Bharat Heavy Electricals Ltd, \\ Tiruchirappalli 620014, India
}

\begin{abstract}
Welding plays a prominent role in the fabrication and erection of structures and components in the industry. Weld failures when they do occur, either during fabrication or service, involve considerable rework, apart from production, time and material losses. Hence, it is essential to adopt appropriate welding procedures depending on the material, weld configuration and the service requirement. In addition, the weldability of the material should be established with adequate laboratory tests in order to minimise the tendency towards hot and cold cracking susceptibilities. The mechanisms of such cracking and the tests to be undertaken to evaluate the cracking susceptibility are enumerated in this paper along with a brief report on weld failures and criteria to be adopted for their repair.
\end{abstract}

Keywords. Weld failures; weld repair; weldability; cold cracking; hot cracking.

\section{Introduction}

Weiding plays a significant role in the fabrication, erection and commissioning of plants and machinery for power, petroleum, chemical, steel and other industrial sectors. With the improvement in steel-making technology and the availability of better and cleaner steel grades with higher strength-to-weight ratios, the capacity, efficiency and availability of plants and machinery are continuously increasing. The advent of better design capabilities, using complex structural analysis with finite element and other methods, has enabled optimisation of section thickness with reduced factor of safety and considerable savings in material and fabrication costs. Manual metal arc welding is being replaced by better, automated and sophisticated welding technologies which reduce the fabrication and erection time considerably and also give better and consistent quality of welds.

The effect of these technological advances is that the pressure parts and other components are now exposed to severe temperature, pressure and environmental conditions for prolonged periods of time which may, sometimes, lead to unforeseen and catastrophic failures. The weldments and heat affected zones (HAZ), which are structurally non-integral with the base metal, are more prone to such failures. Apart from the cost and time required for the weld repair of such components. the plant outage leads to considerable financial losies. Hence, it is important to understand the factors responsible for such 
Table 1. Welding defects and their effects.

\begin{tabular}{|c|c|c|}
\hline Defect & Possible effects & Action \\
\hline $\begin{array}{l}\text { Incomplete } \\
\text { penetration }\end{array}$ & $\begin{array}{l}\text { Reduces strength and notch } \\
\text { toughness }\end{array}$ & $\begin{array}{l}\text { Complete removal } \\
\text { necessary }\end{array}$ \\
\hline $\begin{array}{l}\text { Lack of } \\
\text { fusion }\end{array}$ & $\begin{array}{l}\text { Reduced fatigue strength and static } \\
\text { and impact strength }\end{array}$ & Remove and reweld \\
\hline Undercut & $\begin{array}{l}\text { Reduces fatigue strength, increases } \\
\text { incidence of hot tears }\end{array}$ & Addition of weld metal \\
\hline Overlap & Reduces fatigue strength & Removal by grinding \\
\hline $\begin{array}{l}\text { Slag } \\
\text { entrapment }\end{array}$ & $\begin{array}{l}\text { Irregular and large lenticular } \\
\text { inclusions may reduce strength } \\
\text { and act as sites for initiation of } \\
\text { brittle fracture. }\end{array}$ & $\begin{array}{l}\text { Chipping, cleaning } \\
\text { and rewelding }\end{array}$ \\
\hline Porosity & $\begin{array}{l}\text { Dense porosity reduces load } \\
\text { carrying area and acts as stress } \\
\text { raiser }\end{array}$ & $\begin{array}{l}\text { Excessive amount } \\
\text { necessitates removal \& } \\
\text { rewelding. }\end{array}$ \\
\hline $\begin{array}{l}\text { Incorrect weld } \\
\text { size and profile }\end{array}$ & $\begin{array}{l}\text { Static and fatigue strength may } \\
\text { get affected, may often indicate } \\
\text { presence of other defects e.g. lack } \\
\text { of penetration }\end{array}$ & $\begin{array}{l}\text { Many require } \\
\text { rewelding }\end{array}$ \\
\hline $\begin{array}{l}\text { Poor surface } \\
\text { appearance }\end{array}$ & $\begin{array}{l}\text { Acts as stress raiser and may affect } \\
\text { fatigue strength }\end{array}$ & $\begin{array}{l}\text { Grinding and chipping } \\
\text { followed by welding } \\
\text { may be necessary } \\
\text { where it is particularly } \\
\text { bad }\end{array}$ \\
\hline $\begin{array}{l}\text { Weld or HAZ } \\
\text { cracking }\end{array}$ & $\begin{array}{l}\text { May propagate and lead to brittle } \\
\text { failure }\end{array}$ & Grinding and rewelding \\
\hline
\end{tabular}

weld failures and try to eliminate or at least minimise them to the extent possible. The present paper aims at discussing the various metallurgical and other welding related factors that can cause weld failures and methods of preventing them. Creep, fatigue and fracture mechanics are excluded from the scope of the present paper since they are covered elsewhere in the book. Similarly, corrosion aspects are also outside the purview of this paper.

\section{General considerations for welding}

A wide variety of metals and alloys are used to fabricate the structurals and pressure parts in the industry and a number of welding technologies are available for the same. The welding processes commonly used can be broadly divided into three categories based on the heat input.

(a) Low heat input

1.0 to $1.8 \mathrm{~kJ} / \mathrm{mm}$

(manual metal arc)

(b) Intermediate heat input $\quad 1.8$ to $4.0 \mathrm{~kJ} / \mathrm{mm}$ (submerged arc, metal inert gas, cored wire etc.) 
(c) High heat input

10 to $40 \mathrm{~kJ} / \mathrm{mm}$.

(electroslag, electrogas etc.)

While it is desirable to achieve the fastest possible deposition rate consistent with the properties required as per design, the welding process is generally dictated by several factors such as section thickness, type of joint, welding position, equipment and manpower availability and shop/site environments. Well established welding procedures are adopted in each case with welders trained for that material, joint configuration and welding position.

Despite these precautions, weld failures do occur occasionally, either during the manufacturing stage itself or during service. These failures could be in the form of porosities, lack of fusion, crack etc. which will have a direct bearing on the performance of the component. Table 1 lists some of these defects, their possible effects and remedial actions to be taken on them.

\section{Welding of structural and pressure vessel steels}

A large number of steel grades are extensively used in welding fabrication. They can be classified into three broad categories (Doty 1970) for their usage in structural and pressure vessel welding fabrication (table 2). Apart from carbon and low alloy steels, several grades of high alloyed and microalloyed steels are also used for specialised fabrication.

Generally all steel grades, either in the plate or pipe form, are amenable for all welding processes. The plate material composition, however, can affect the following mechanical and metallurgical properties of the welded joints.

Table 2. Classification of structural and pressure vessel steels (Doty 1970).

\begin{tabular}{|c|c|c|}
\hline Composition & Thermal history & $\begin{array}{l}\text { Minimum yield } \\
\text { strength }\left(\mathrm{N} / \mathrm{mm}^{2}\right)\end{array}$ \\
\hline Carbon & $\begin{array}{l}\text { Non heat treated } \\
\text { Normalised } \\
\text { Quenched \& tempered }\end{array}$ & 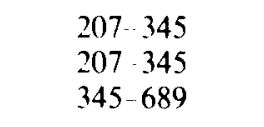 \\
\hline $\begin{array}{l}\text { Low alloy } \\
\text { steels** }\end{array}$ & $\begin{array}{l}\text { Non heat treated } \\
\text { Normalised } \\
\text { Quenched \& tempered }\end{array}$ & $\begin{array}{l}276 \quad 482 \\
345-413 \\
413 \quad 689\end{array}$ \\
\hline $\begin{array}{l}\text { Alloy } \\
\text { steels*** }\end{array}$ & $\begin{array}{l}\text { Normalised } \\
\text { Normalised \& tempered } \\
\text { Quenched \& tempered }\end{array}$ & $\begin{array}{ll}241 & 345 \\
345 & 552 \\
345 & 1241\end{array}$ \\
\hline * & \multicolumn{2}{|c|}{$\begin{array}{l}0.33 \% \text { max. C. C- } \mathrm{Mn} \mathrm{Si} \text { and with certain } \\
\text { alloying elements. }\end{array}$} \\
\hline ** & \multicolumn{2}{|c|}{$\begin{array}{l}0.26 \% \max . \mathrm{C}, \mathrm{C} \text { with upto about one percent } \\
\text { total of } \mathrm{Cu}, \mathrm{Ni}, \mathrm{Cr}, \mathrm{V} \& \mathrm{Nb} \text {. }\end{array}$} \\
\hline$* * *$ & \multicolumn{2}{|c|}{$\begin{array}{l}0.25 \% \text { max. C. C with } 0.5 \% \text { or more of Ni.Cr or } \\
\text { Mo. }\end{array}$} \\
\hline
\end{tabular}


- Mechanical strength of the joint;

- Fracture toughness of the base metal, HAZ and weld metal;

- HAZ cracking sensitivity;

- Weld metal cracking sensitivity;

- Stress corrosion susceptibility.

Adequate precautions are to be taken to eliminate the above mentioned problems. The relationship between heat input, chemical composition and thickness must be reasonably defined in a practical manner and the effects of general and local restraint taken care in establishing adequate welding procedures.

\section{Welding of stainless steels}

Among the stainless steels, austenitic stainless steels are used for more than $90 \%$ of the fabrication because of their excellent weldability (Castner 1993). They have lower melting points, higher electrical resistance, lower coefficients of thermal conductivity and higher coefficients of thermal expansion than carbon steels. Austenitic stainless steels are amenable to all welding processes if a few of the factors are taken into account.

- Solidification cracking is the most frequently encountered problem;

- autogenous welds may be subjected to variable penetration;

- the welding procedure may affect corrosion resistance;

- several factors must be considered if post weld heat treatment (PWHT) is required;

- welding of austenitic stainless steels can result in greater distortion than carbon steels;

- welding fumes present potential hazard to workers;

- dissimilar metal weld joints require proper selection of filler metals and procedures.

Solidification cracking is a problem when the welds solidify primarily as austenite. Instead, if the weld metal is solidified primarily with delta ferrite, the hot cracking propensity is the least. The delta ferrite content can be estimated by Schaeffler and Delong diagrams. Presently, the Welding Research Council (WRC) has published modified diagrams in 1992 (figure 1) that allow accurate prediction of delta ferrite number (FN) in austenitic stainless steels.

A number of sources recommend a minimum of $4 \mathrm{FN}$ to prevent hot cracking in arc welds of austenitic stainless steels. However, in certain situations involving higher welding speeds and deep and narrow weld beads, this may not be adequate to prevent hot cracking and hence a higher range of 5-20 FN is recommended. Care must be taken not to go for higher $\mathrm{FN}$ where the possibility of sigma phase formation increases.

Minor variation in the chemical composition of austenitic stainless steels can sometimes cause problems of variable penetration for autogenous full penetration welds. These problems referred to as 'cast-to-cast' or 'heat-to-heat' variation are particularly evident in heats containing less than $0.003 \%$ sulphur. They are always associated with the surface active elements on the fluid flow of the metal. Recommendations to avoid variable penetration include; avoiding calcium and rare earth treated steels, avoiding steels with less than $0.005 \%$ sulphur and with aluminium content of higher than $0.02 \%$. When such steels have to be used, careful control of process parameters have to be worked out. 


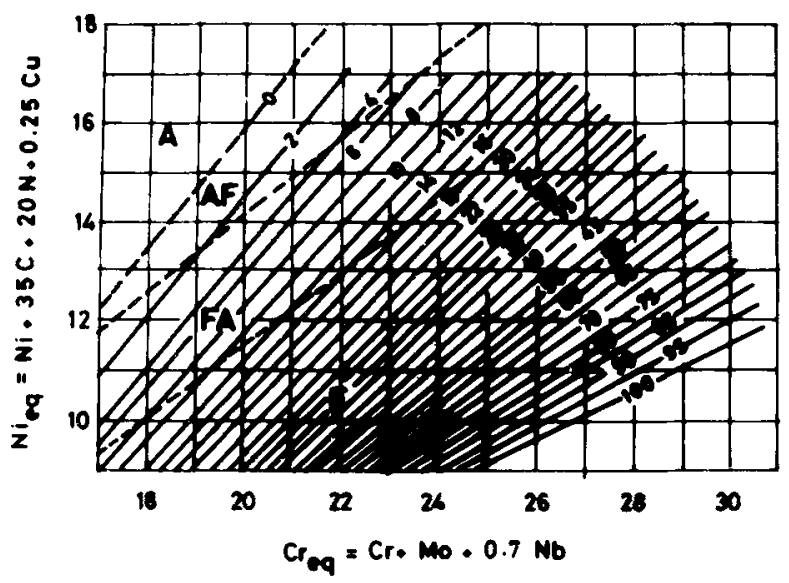

Figure 1. Welding Research Council (1992) constitutional diagram for stainless steel welds.

Welding can reduce corrosion resistance of $\mathrm{HAZ}$ regions that are exposed to temperatures between 425 and $900^{\circ} \mathrm{C}$ for long enough time to precipitate chromium carbide at grain boundaries. The most widely used method to prevent sensitisation of $\mathrm{HAZ}$ is to use low carbon stainless steel. Another approach is to use stabilized grades that contain titanium or columbium. Low carbon stainless steels have lower strengths than stabilized grades. Stabilized grades, on the other hand, may be more hot crack sensitive and may require careful ferrite control. They may also be susceptible to the localised precipitation of carbides in narrow regions of $\mathrm{HAZ}$ that can lead to intergranular corrosion known as knifeline attack.

Austenitic stainless steel weldments are normally used in service in the as-welded condition. However, to minimise residual stresses, prevent distortion and also in environments that can cause stress corrosion cracking, PWHT may be required.

The PWHT must be done in such a way as to avoid the following problems.

- Heating in the range $425-900^{\circ} \mathrm{C}$ can result in sensitisation.

- Heating weld between 540 and $925^{\circ} \mathrm{C}$ can transform ferrite to a hard brittle sigma phase.

For these reasons, PWHT usually involves solution annealing at temperatures of $1065-1120^{\circ} \mathrm{C}$ followed by rapid cooling or water quenching. Sigma phase can be minimised if the weld metal FN is limited to $10-12 \mathrm{FN}$.

\section{Weldability}

As mentioned earlier, depending on the heat input, the consumables used, the restraint on the weld and the cooling rate, a weld failure which manifests as porosity, lack of fusion or cracking may occur. To understand these behaviours, it is essential to study the weldability of the material. Weldability has been defined by the International Institute of Welding (IIW. document no. IIW/IIS-22-59) as: "A metallic material is considered to be weldable to a certain degree by a given process and for a given purpose when a continuous metallic connection can be obtained by welding using 
a suitable procedure so that the joints comply with the requirements specified both in regard to their local properties and their influence on the construction of which they form a part'.

This definition properly refers to both metallurgical and structural standpoint. Thus, any test to evaluate the weldability of a material should take into account all aspects of welding, the heating cycle, the cooling cycle, the stresses induced during solidification and fusion, and also the structural variations. All these factors, individually or collectively, can cause cracking in the weldments. The weldment cracking is broadly classified into two categories: cracks which develop above the solidus of the metal are called 'supersolidus cracks' and those that develop below the solidus temperature are called 'subsolidus cracks'. They are also commonly referred to as 'hot cracks' and 'cold cracks' depending on the temperature at which they develop.

\section{Cold cracking in weldments}

Cold cracking essentially depends on the underbead hardness, the hardness of the HAZ and the restraint imposed on the structure during cooling. The maximum possible hardness of the steel depends primarily on its carbon content. It is also influenced by the other chemical elements present in the steel and the weld thermal cycle. The methods of predicting the hardness have, by and large, focussed on defining and determining the carbon equivalent of the steel which takes into account the effect of various alloying elements. The effect of restraint history is evaluated separately by weldability tests such as implant and controlled thermal severity tests. The effect of thermal history is evaluated by determining/predicting the microstructure in weld simulation during cooling between 800 and $500^{\circ} \mathrm{C}$.

Cold cracking is also sometimes referred to as hydrogen-induced cracking (HIC) since hydrogen is known to play a major role in this method of cracking. In ferritic steels, the phase changes which accompany weluing may lead to hardened structures (like martensite formation) in either the weld metal or HAZ or both. These structures have low ductility which is further reduced by the presence of hydrogen, unavoidably introduced into the weld. This is because the solubility of hydrogen decreases as the temperature decreases. When the austenite contains hydrogen, the transformation during cooling results in the liberation of molecular hydrogen. In such cases, cracking or brittle fracture may occur following welding under the influence of residual stress and applied stress from the system (Baker et al 1966). The critical hardness levels of the weld will alter with type of joint, hydrogen potential of the welding process and the strength and composition of the parent metal. A typical cold crack is shown in figure 2.

\subsection{Carbon equivalent}

While assessing a plate material for its cold cracking susceptibility due to welding, the important aspect of carbon equivalent (CE) should be taken into account. The limiting value of $\mathrm{CE}$ is, in essence, an index of the $\mathrm{HAZ}$ hardening that may be allowed without cracking and this affects the rate of cooling which can occur during welding. Also for a given value of carbon equivalent, there is a thermal conductivity balance which necessitates higher preheat temperatures to avoid HAZ cold cracks in thicker plates. 


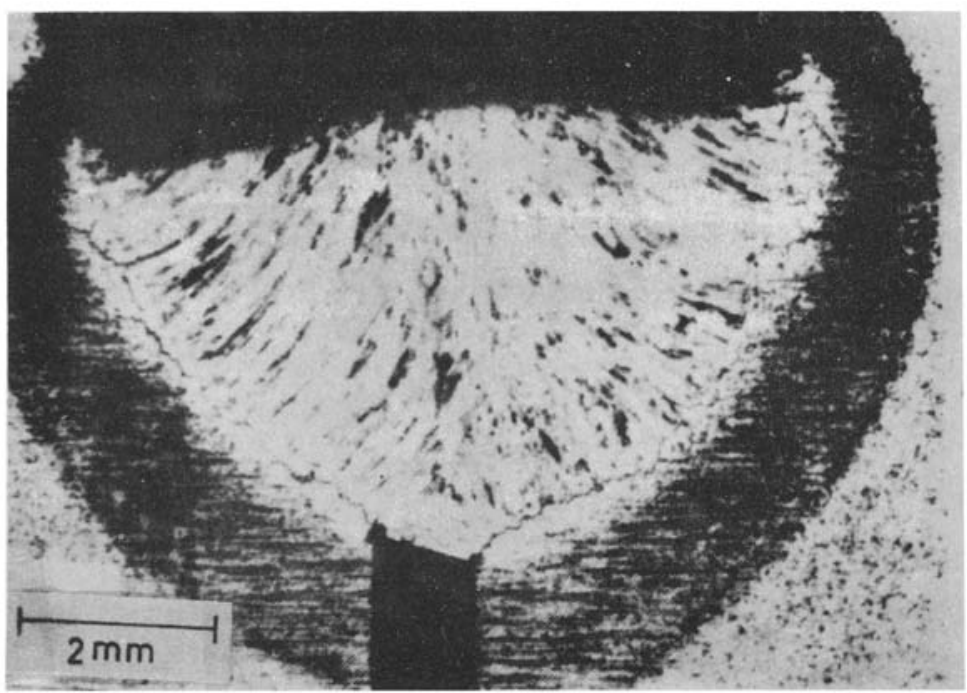

Figure 2. Cold cracking in the root run of butt weld.

A large number of carbon equivalent formulae have been proposed by different workers (de Meester 1991) which essentially predict the hardenability of the steel. Among these, the most widely used is the IIW carbon equivalent formula proposed by Dearden \& O'Neil in 1940 and incorporated in the national standards of various countries.

$$
\mathrm{CE}_{\text {II }}=\frac{\mathrm{C}+\mathrm{Mn}}{6}+\frac{\mathrm{Ni}+\mathrm{Cu}}{15}+\frac{\mathrm{Cr}+\mathrm{Mo}+\mathrm{V}}{5} \text {. }
$$

This formula can be conveniently used for steels with carbon content of more than $0 \cdot 18$ or for steels with $t_{800 / 500}$ cooling time of longer than about $12 \mathrm{~s}$.

The preheat temperatures suggested for several ranges of equivalent carbon content are:

$\begin{array}{cc}C E & \begin{array}{c}\text { Suggested preheat } \\ \text { temperature }\end{array} \\ \text { Upto } 0.45 \% & \text { Optional } \\ 0.45 \text { to } 0.60 \% & 95 \text { to } 200 \\ \text { above } 0.60 \% & 200 \text { to } 370\end{array}$

The above suggested preheat temperatures are for arc welding processes. They may be affected by the thickness of the workpiece. For gas welding processes, however, preheating is usually not required owing to the slow cooling rates associated with such processes.

\subsection{Effect of hydrogen}

More than $50 \%$ of the in-service failures, to date, have been attributed to the hydrogen induced cracking. The accident at the off-shore oil drill platform of North Sea in Ireland (Alexander 1981), the failure of the first stage rocket motor casing during 


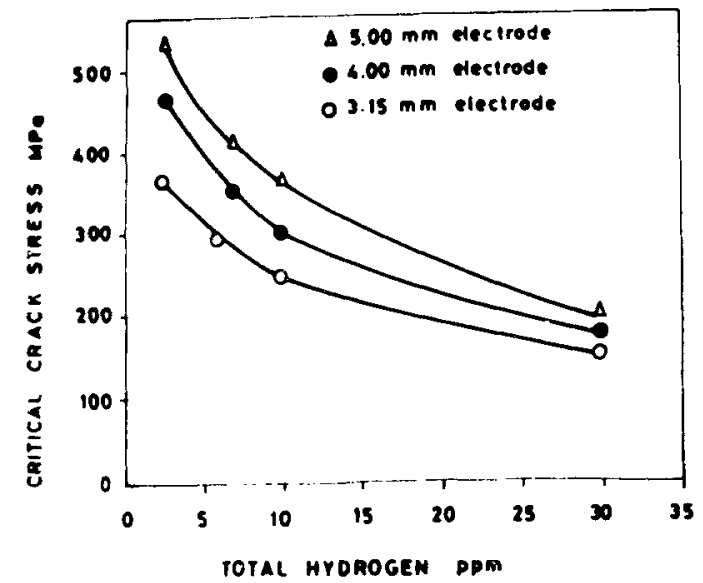

(a)

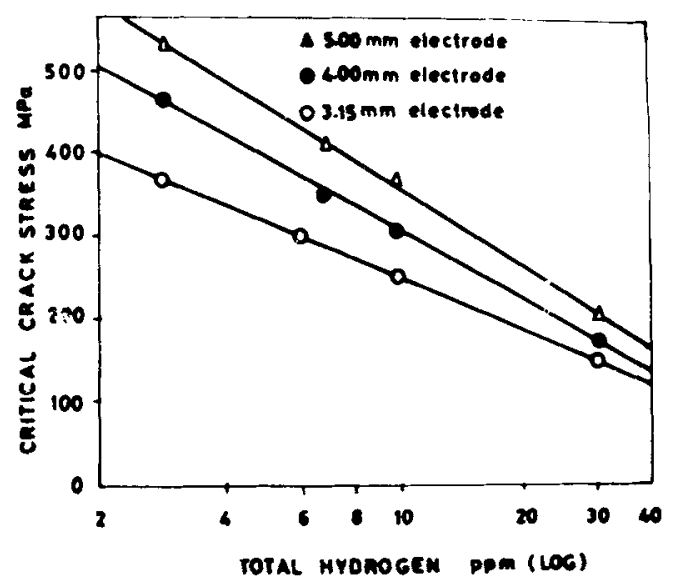

(b)
Figure 3. Critical crack stress determined by implant tests on carbon steel vs total hydrogen (ppm) plotted on (a) linear and (b) logarithmic scale (Evans \& Christensen 1971).

hydrotest at NASA (Kula \& Anetil 1977) and the brittle fracture of an ammonia pressure vessel (Rosenfield \& Reid 1977) are some of the major weld failures that have been reported and attributed to HIC.

Hydrogen is inadvertently introduced during welding in the weld metal. During cooling, this gas diffuses rapidly towards HAZ while the solidification and phase transformation progress in the opposite direction. This explains the formation of 'underbead cracking' in the HAZ close to the fusion boundary in which hydrogen is known to play a major role.

Among the techniques for diffusible hydrogen measurement, the glycerine method, mercury method and gas chromatography method are popular. The glycerine method, which was almost exclusively used in 50 's and 60 's is now considered not very accurate because some of the hydrogen dissolves in glycerine. The IIW and the American Welding Society (AWS) committees are trying to standardise the test conditions for mercury and gas chromatography methods and a detailed status report can be found in the literature (Kotecki 1992). 
There has also been considerable work on the effect of diffusible hydrogen on cracking. Many researchers (Evans \& Christensen 1971) have examined the critical cracking stress by the implant test of a variety of steels as a function of hydrogen content in the weld metal. Figures $3 a$ and $3 b$ show the data for a $0.17 \% \mathrm{C}$ and $1.36 \% \mathrm{Mn}$ steel and it is apparent that the critical cracking stress (implant rupture stress) is a linear function of the logarithm of the hydrogen content. Another method of representing the data is via the critical preheat temperature needed to avoid cracking as a function of diffusible hydrogen and hardenability; the latter expressed as carbon equivalent. The results are shown in figures $4 a$ and $4 b$ (Christensen \& Simonsen 1981) and again the critical $\mathrm{CE}$ at a given preheat temperature is an approximate linear function of the logarithm of the weld metal diffusible hydrogen. Similar analysis has been conducted by other workers also (McParlan \& Graville 1976).

Atternpts are being made to develop and introduce low and very low hydrogen electrodes in order to combat the above problem. The AWS specifications (A5.1 and 5.5 ) define a "low hydrogen coated electrode" as having no more than $0.6 \%$ moisture

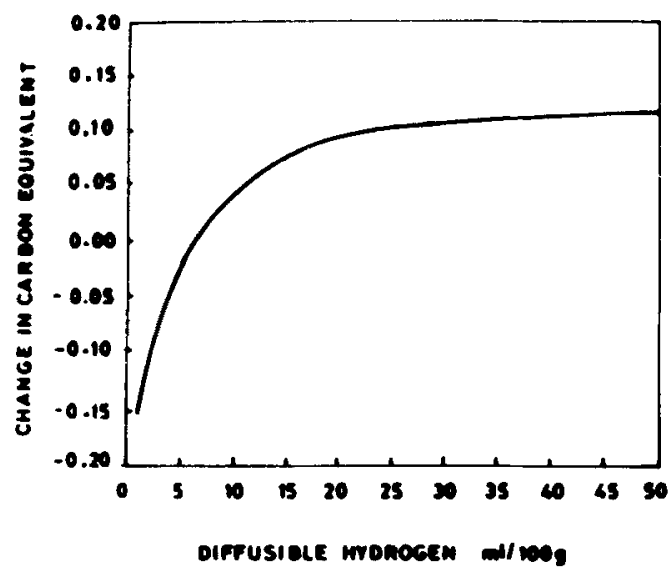

(a)

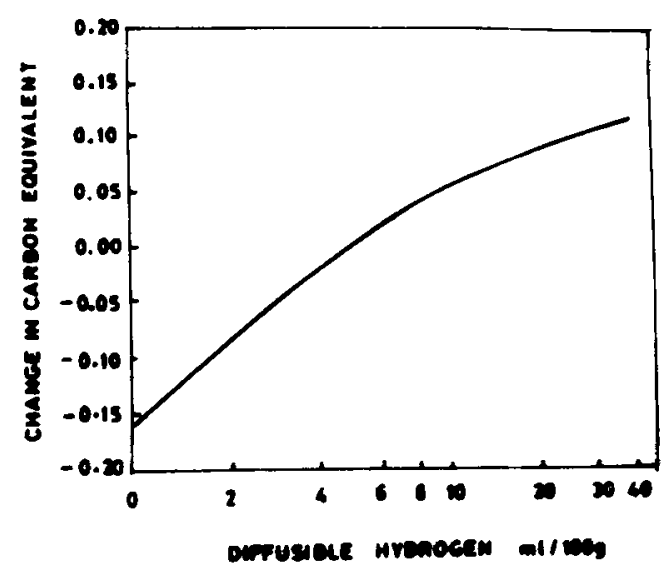

(b)
Figure 4. Carbon equivalent adjustment plotted against diffusible hydrogen on (a) linear and (b) logarithmic scale (Christensen \& Simonsen 1981). 
content. The IIW definition of 'hydrogen controlled electrodes' are those producing $15 \mathrm{ml} / 100 \mathrm{~g}$ of hydrogen with $10 \mathrm{ml}$ and $5 \mathrm{ml} / 100 \mathrm{~g}$ defining progressively better consumables. The $15 \mathrm{ml} / 100 \mathrm{~g}$ compares well with 0.6 percent coating moisture of AWS specification, while $16 \mathrm{ml} / 100 \mathrm{~g}$ plotted on a logarithmic scale fits in exactly with $0.6 \%$ moisture. Hence, the AWS committee, (Kotecki 1992) has decided to introduce three designations ' $\mathrm{H} 16$ ', ' $\mathrm{H} 8$ ' and ' $\mathrm{H} 4$ ' corresponding to hydrogen levels of 16, 8 and $4 \mathrm{ml} / 100 \mathrm{~g}$ respectively. This system would be introduced for covered mild steel electrodes (ANSI/AWS A5·1), covered low alloy steel electrodes (A5·5), submerged arc mild steel wires and fluxes (A5.17), submerged arc low alloy steel wires and fluxes (A5·23), gas shielded mild steel wires (A5·18), gas shielded low alloy steel wires (A5·28), flux cored mild steel wires (A5.20) and flux cored low alloy steel wires (A5.29). Some of these eight specifications have since been introduced and others are in the process of being revised. For all critical applications these low hydrogen consumables can be used to minimise the problem of HIC.

\subsection{Weldability tests for cold cracking}

The susceptibility of a steel for cold cracking depends on a multitude of events that any single test employing a set of standard parameters cannot adequately and with a degree of certainty quantitatively predict the cracking susceptibility (Veeraraghavan et al 1988). Controlled thermal severity and implant tests have been used for long to evaluate the cold cracking susceptibility.

Controlled thermal severity (CTS) test (Granjon 1960) consists of two plates with varying thicknesses fastened to one another by a central bolt and two lateral weld beads, called anchor runs- $C_{1}$, are run (figure 5). The test beads $C_{2}$ and $C_{3}$ are run in a sequential order with the assembly being preheated to a select temperature. Since the assembly is not symmetrical, the bead $\mathrm{C}_{3}$ cools more rapidly then the bead $\mathrm{C}_{2}$ which has a lower thermal severity. The cooling rate in the critical zone can be modified by varying the plate thickness and the preheating temperature. Combined thickness of the plates, expressed in quarters of an inch is denoted as the thermal severity number (TSN). Fillet welding is done with increasing thickness until cold cracking occurs at a particular TSN. The demerit of this test is that the plate thickness determines both the HAZ hardening tendency as well as restraint values which cannot be varied independently.

The implant test, also proposed by Granjon (1969), is also being widely used to evaluate the cold cracking susceptibility. The standard procedure has been specified by the IIW and incorporated in the national standards of several countries. It is essentially a constant load rupture test of real HAZ of a steel immediately after welding. Taking fracture of specimen as a criterion, the critical stress applied for fracture at specific conditions of welding can be evaluated which can serve as an index to describe the hydrogen induced cracking susceptibility of the steel. One can also evolve the welding conditions under which the critical stress $\left(\sigma_{\mathrm{cr}}\right)$ cracking will be brought equal to or a specified percentage of the yield strength in order to select a welding procedure for the steel.

Many times cracks have been found to develop despite the above mentioned tests indicating positive results. This is because in most of the cases, the rigidity of the structure or the restraint which is not exactly quantified, is the contributory factor for 

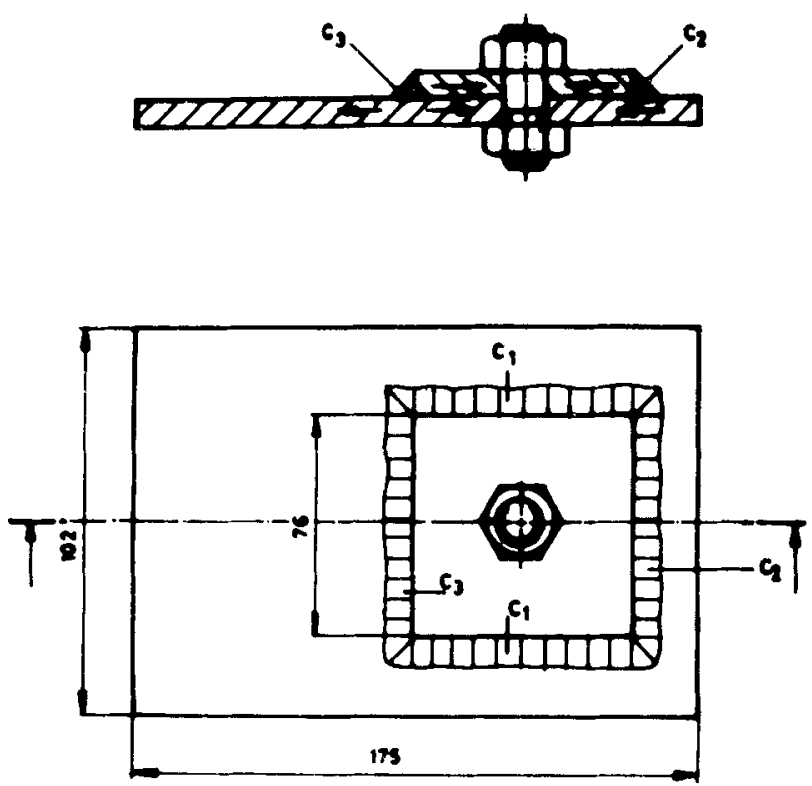

$C_{1}$-Ancher runs $C_{2}$ - eimermel bead $C_{3}$ - Trimernal bees
Figure 5. Controlled thermal severity test.

the cold cracking in welds. To overcome this problem, Rigid Restraint Cracking (RRC) tests (Satoh \& Matsui 1968) were developed. In RRC tests, specimens prepared for butt weld are perfectly rigidly clamped during welding and cooling down period, and the restraint intensity is measured. It is varied by varying the specimen length. The test enables one to assess the critical reactive stress $\left(\sigma_{\mathrm{cr}}\right)$ and the critical restraint intensity $\left(K_{\mathrm{cr}}\right)$ for a given material, under a set of welding conditions.

The disadvantages of the above test are that it requires sophisticated equipment for perfect clamping and maintaining constant gauge length during testing. Also long lengths of specimens are needed for obtaining low restraint intensity which increases the material requirement and cost.

To obviate these disadvantages, alternate methods known as Elastic Restraint Cracking (ERC) tests were developed at CSSR and elsewhere. Of these, the test method developed by Povezan (1978) of Bratislava Welding Research Institute has been adopted by us in WRI, Tiruchirapalli and is shown in figure 6. Window type elastic frames are used and the test plates are clamped by means of high strength bolts. The side arms of the clamping elements are provided with resistant strain gauges enabling recording of the reactive force during the tests. The effective restraint of the weld joint will depend upon the restraint intensity of the frame, restraint intensity of specimen and the length of the weld bead deposited. The development of weld reactive force is monitored with a time chart recorder. After allowing a day for development of cold crack, the weldment is evaluated by NDT and metallography for the presence of crack which can easily be correlated with the weld reactive force data. The test method is economical and easy to conduct and can serve as a standard test for the evaluation of cold cracking susceptibility of structural steels. 

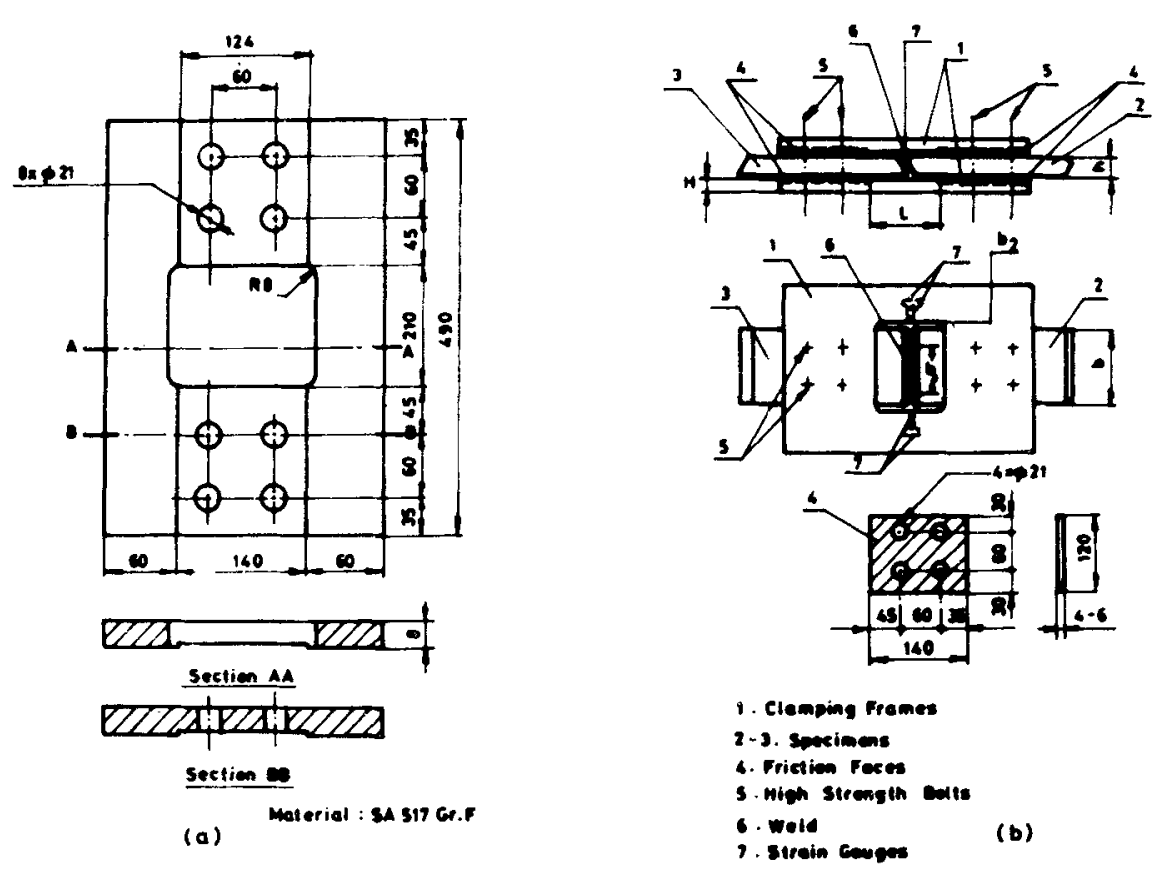

Figure 6. (a) Restraining frames for ERC test; (b) ERC test assembly (Veeraraghavan et al 1988).

\section{Hot cracking in weldments}

Hot cracking in weldments develop during or after solidification and are generally associated with the phase transformation and shrinkage strains. Depending on the conditions of cracking, they are classified as solidification cracking, liquation cracking, lamellar tearing and reheat cracking.

Many types of hot cracking tests have been proposed to evaluate the weldability of materials (Wilken \& Schoenherr 1975). They are divided into two categories: self restraint type and external restraint type. Typical examples of self-restraint tests are the Houldcraft test and the Lehigh restraint tests. However, these tests give rise to considerable scatter in the results due to their inability to reproduce strain fields. These strain fields depend on the thermal pattern which is largely uncontrollable. Typical methods which use external restraint forces are the Varestraint test and the tensile restraint cracking test with bending and/or tensile restraint respectively.

\subsection{Solidification cracking}

During solidification of the weld metal, grains grow from the fusion boundary to the central region of the weld pool, impurities and alloying elements are rejected ahead of the growing crystals and become more and more concentrated in the liquid that solidifies later. Their presence lowers the melting point of this liquid. As solidification proceeds, contraction strains will develop across the weld as a result of the cooling of 


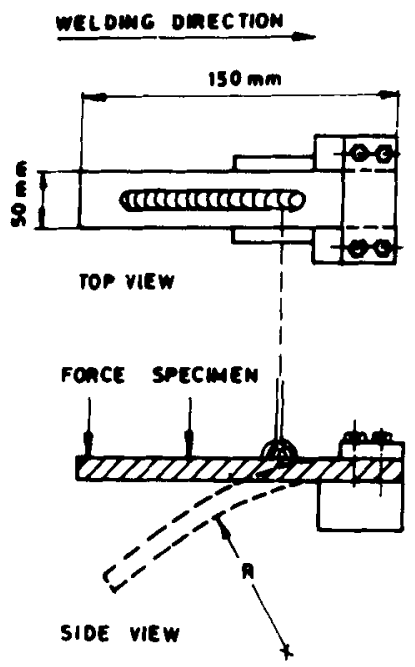

(a)

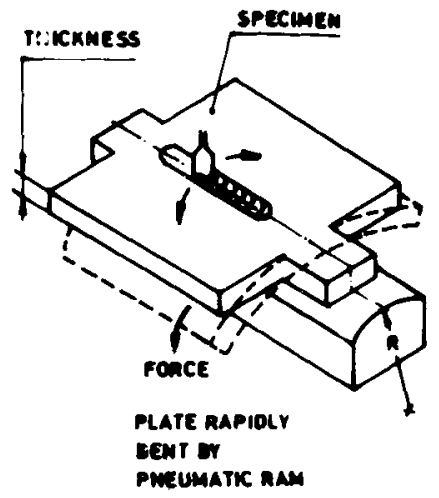

(c)
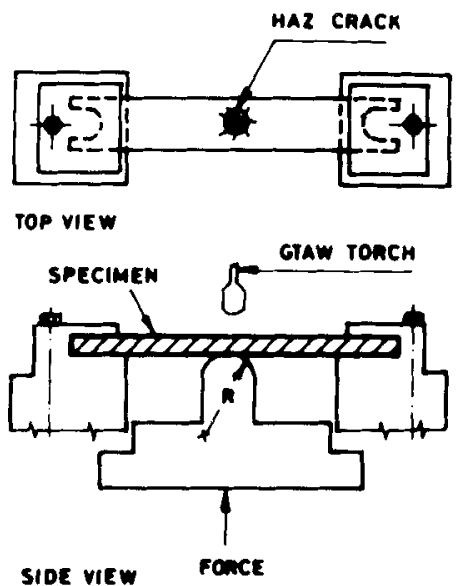

(b)

Figure 7. Schematic illustration of (a) varestraint test, (b) spot varestraint test and (c) transvarestraint test.

the weld and the surrounding material. If the ductility is lowered sufficiently by the persistence of the liquid films, cracking may result longitudinal to the weld bead.

The incidence of this problem is most likely in high dilution processes such as the welding of the root run and submerged arc welding of plates. Another form of crack transverse to the weld is also possible. Thus, a satisfactory assessment procedure should fulfil:

(a) application of controlled strain both longitudinally and transversely about the test weld;

(b) determination of critical strain parameter as a function of dilution;

(c) assessment of welding techniques like TIG, SMAW and SAW;

(d) correlation must be established between test results and practical joints

Such tests for assessing solidification cracking could be carried out using both Varestraint (Savage \& Lundin 1965) and the Transvarestraint rests (McKeown 1970) 
Both these tests satisfy the requirements ' $a$ ' to ' $c$ ' but further work is required to establish ' $d$ '. A third variant of the test called Spot-Varestraint test ('Tigama-Jig test) has also been developed (Savage et al 1977). All these tests are schematically illustrated in figure 7 (a to c).

All these tests are similar in principle and differ only in the direction of application of strain with respect to weld direction. The test piece is a flat plate fixed at one end (figure $7 \mathrm{a}$ ) or at both ends (figure $7 \mathrm{~b}$ ) or in the middle (figure 7c) on a rigid block the surface of which comprises a cylinder of radius $R$. After the weld is run to a certain length (figures $7 \mathrm{a} \&$ c) or at a spot (figure $7 \mathrm{~b}$ ) the plate is rapidly bent against the cylindrical part of the block. The test severity is expressed in terms of the strain which varies with the plate thickness and with the radius $R$. It is relatively easy to evaluate the susceptibility to cracking by the strain above which the cracks appear or by the total length of the crack for a given strain. Several investigators have used different criteria for interpretation of result of varestraint tests (figure 8) (Dixon 1983). The degree of cracking can be quantified by the average crack length, or the total number of cracks, or the maximum crack length or the cracked HAZ length - all as a function of strain. Thus, considerable subjectivity exists in the interpretation of results.

In addition to the varestraint tests, hot ductility tests can also be used to quantify the HAZ cracking susceptibility. The hot-ductility test characterises the ductility of the material at elevated temperatures and relates this data to the cracking susceptibility. Basically, small tensile specimens are fractured rapidly at some specific temperatures during either heating or cooling cycles of a thermal cycle in a thermomechanical simulator. The transverse reduction in area of the fractured sample is subsequently determined providing a measure of ductility. Both the on-heating and on-cooling curves in the vicinity of the solidus temperature can be obtained as shown in figure 9 and the nil ductility temperature (NDT), nil strength temperature (NST) and the ductility recovery temperatures (DRT) determined. In addition to the hot ductility, the hot strength of the material can also be evaluated.

In order to obviate the sutjectivity in the interpretation of data in the above tests, Lin et al (1993) have evolved a new methodology for quantifying HAZ liquation cracking susceptibility by defining the thermal crack susceptibility of the region of the material, which is a material specific parameter. This region can be determined using Gleeble hot

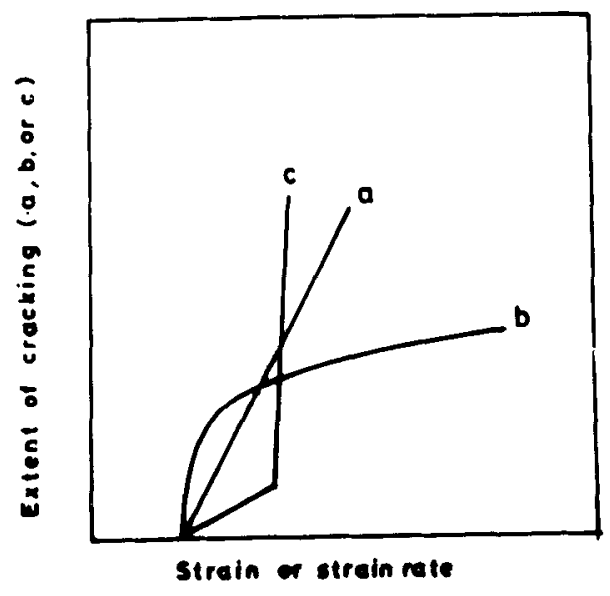

Figure 8. Shape of graphs obtained by the different testing procedures: (a) Average crack length vs. strain (Farrar \& Garland 1973), crack area vs strain rate (Konishchev et al 1977), number of cracks $v \mathrm{~s}$ strain (Nakagawa et al 1974). (b) Maximum crack length vs strain (Savage \& Lundin 1965). (c) Modification to (a) by Bailey (1978). 

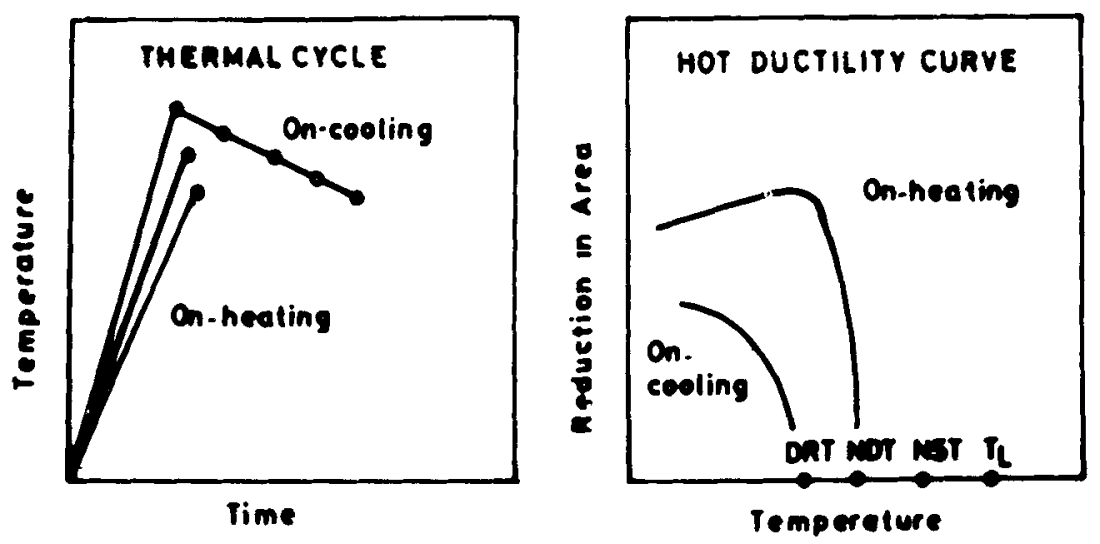

Figure 9. Representation of results obtained from hot ductility test. DRT - ductility recovery temperature, NDT - nil ductility temperature. NST - nil strength temperature, $T_{L}$-- liquation temperature.

ductility, spot or longitudinal varestraint tests. However, the authors also acknowledge that these data alone cannot easily accommodate the variations in weld restraint that often dictate the occurrence and severity of cracking.

A similar comparative study of hot ductility rate test and modified varestraint tests were attempted in Germany over a wide range of materials obtained from different steel manufacturers (Rawlings \& Wilken 1992). In the hot ductility test, the maximum transverse deformation rate which can be endured without causing hot cracking on the surface of the weld deposit was used as the criteria. In the varestraint test, the total length of all the hot cracks found under the stereomicroscope at a magnification of $25 \mathrm{X}$ was used as the criteria. Remarkably good correlations were obtained between the two methods on all the materials tested by SMAW, TIG and MIG techniques. The results are under discussion for standardisation by the German Welding Society.

\subsection{Burning or liquation cracking}

At the high temperatures reached during welding in the $\mathrm{HAZ}$ adjacent to the fusion boundary, local melting may occur as a result of the presence of non-metallic impurities giving rise to the phenomenon known as 'burning' (Boniszewski \& Watkinson 1964). These cracks are intergranular with respect to prior austenite grains and occur in the HAZ normal to the fusion line of the weld (figure 10a). Hemsworth et al (1969) classified such cracks, also sometimes known as 'hot tears', depending on whether they occurred because of the segregation leading to grain boundary liquation or precipitation of brittle constituents or a loss in ductility dip and consequent tearing.

In ferritic steels the problem is principally caused by carbon, sulphur, phosphorus and manganese. An increase in the concentration of the first three elements and a decrease in the concentration of the fourth one leads to an increase in the incidence of cracking. Control of this problem lies in the ability to avoid susceptible compositions with due care to the welding process, trace elements and other deleterious factors. Carbide formers are helpful in that they remove the carbon from the solution. Increase 

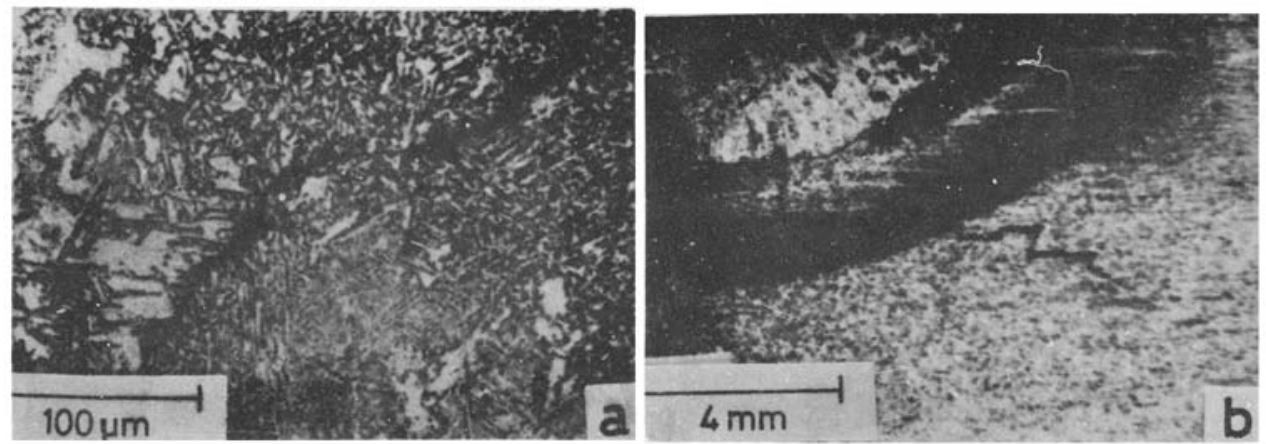

Figure 10. (a) Hot tear across $H A Z$ and weld metal and (b) lamellar tearing in T-butt weld.

in manganese content and, in general, a higher $\mathrm{Mn} / \mathrm{S}$ ratio is considered helpful (Meitzner \& Stout 1966).

A possible test for detecting liquation cracking is by mechanical testing of specimens at elevated temperatures during a simulated HAZ thermal cycle. A cylindrical test specimen is heated by resistance or induction heating and the strength and ductility are measured either at the peak temperature or immediately after, and these properties are correlated with the occurrence of burning and liquation cracking in the HAZ of the welds made with specific levels of heat input (Widgery 1971).

\subsection{Lamellar tearing}

The problem of weld failures has become more common with increased use of higher strength and thicker steels, particularly where the plate material is welded normal to its surface with high restraint being imposed, as in the case of full penetration T-butt welds. The problem may arise where high strain rates may develop in the short transverse direction of a plate. Cracking may result which is primarily due to the presence of inclusions lying on planes parallel to the plate surface which reduces the short transverse ductility. Substantial parts of the fracture path lie in planes parallel to the surface of the plate. In contrast to HIC, lamellar tearing may propagate both within and outside the visible HAZ (figure 10b). A tensile test is the simplest of the destructive tests for examining the short transverse properties. Measurement of reduction in area has been shown to correlate well with fabrication susceptibility to lamellar tearing (Farrar et al 1969). Some anomalies can be expected where plates of low inclusion content show low values of reduction in area, and this can arise when individual inclusions are large compared with the specimen cross-section area.

\subsection{Reheat cracking}

When a weld joint is reheated after welding, whether for stress relief or during service, the residual stress remaining after welding will be relaxed by high temperature deformation. This relaxation is accompanied by plastic deformation in the weld metal and HAZ and, at points of stress concentration such as the toes of fillet welds, the degree 
Table 3. Weld cracks and methods of testing.

\begin{tabular}{lll}
\hline $\begin{array}{l}\text { Potential } \\
\text { problem }\end{array}$ & \multicolumn{1}{c}{ Specification tests } & \multicolumn{1}{c}{$\begin{array}{c}\text { Batch quality } \\
\text { control tests }\end{array}$} \\
\hline $\begin{array}{l}\text { Hydrogen } \\
\text { induced cracking }\end{array}$ & $\begin{array}{l}\text { Continuous cooling transformation } \\
\text { assessment } \\
\text { Fracture mechanics susceptibility } \\
\text { tests } \\
\text { Granjon implant test }\end{array}$ & $\begin{array}{l}\text { Chemical analysis } \\
\text { Taper hardness test }\end{array}$ \\
$\begin{array}{l}\text { Solidification } \\
\text { cracking }\end{array}$ & $\begin{array}{l}\text { Varestraint and transvarestraint } \\
\text { test }\end{array}$ & Hot deformation rate test \\
$\begin{array}{l}\text { Burning or } \\
\text { liquation } \\
\text { cracking }\end{array}$ & $\begin{array}{l}\text { High temperature test on thermally } \\
\text { simulated specimen }\end{array}$ & $\begin{array}{l}\text { Side or face bend } \\
\text { tests }\end{array}$ \\
Lamellar tearing & $\begin{array}{l}\text { Short transverse tensile test } \\
\text { Crack notched bend test } \\
\text { Automated inclusion counting }\end{array}$ & $\begin{array}{l}\text { Ultrasonics } \\
\text { S T tensiles } \\
\text { Automated inclusion } \\
\text { counting }\end{array}$ \\
Reheat & $\begin{array}{l}\text { Fracture mechanics stress } \\
\text { relaxation and constant load tests } \\
\text { cracking }\end{array}$ & - \\
\hline
\end{tabular}

of local strain may be considerable. In certain steels with poor high temperature ductility, the deformation may be too great to be accommodated and cracking may result. Such cracks, known as reheat cracks or stress relief cracks, are intergranular in nature and appear in the $\mathrm{HAZ}$ and occasionally in the weld metal.

Historically, reheat cracks were observed in austenitic stainless steels SS 347,321 and then in other grades of low alloy steels used in superheaters, turbine rotors, forgings etc. (Dhooge \& Vinckier 1992). After extensive investigations, Lundin \& Khan (1990) concluded that chemical composition is the most significant factor in PWHT cracking. The elements found to be deleterious are either those that promote formation of carbides of $\mathrm{M}_{2} \mathrm{C}$ or $\mathrm{M}_{4} \mathrm{C}_{3}$ types or those which are known to have grain boundary embrittling effects.

Multitude of tests have been employed by different researchers to evaluate reheat cracking and the test results are difficult to compare and sometimes confusing (Lundin \& Khan 1990). The remedy against reheat cracking is careful dressing of the surface of the weld. Temper beading, if correctly performed, combined with weld dressing, should provide a microstructure and surface favourable for avoiding initiation and propagation of cracks.

The various forms of cracking discussed above and the possible tests for evaluating the cracking susceptibility are tabulated in table 3 .

\section{Weld failures and their repair}

Weld failures can be broadly divided into two categories: first, failures that occur during fabrication when a weldment fails to satisfy appropriate inspection criteria, e.g. 
undercut or porosity which may exceed the permitted limits or more seriously, flaws such as hydrogen cracking. These are normally repair welded with adequate precautions and using well-established repair procedures. The second category covers weldments that experience cracking or are damaged during service. These include fatigue cracking, stress corrosion cracking and fracture. Their repair may be difficult and time consuming and in some cases, the failure may be in inaccessible locations without adequate data on the previous history of the components involved which makes weld repair very difficult. All the factors to be considered during the weld repair are enumerated in the IIW Commission XV in their document No. IIS/IIW956-87.

In this context, the 'fitness-for-purpose' approach using fracture mechanics concepts and a thorough knowledge of the stress, imperfection size and material properties, help in taking crucial decisions on whether to repair a weld crack which may not propagate under the given service conditions. In fact, there is considerable evidence that the repair of innocuous imperfection may be positively harmful when working to arbitrary acceptance criteria. Three case studies from literature will be briefly described to illustrate the three conditions enumerated above.

What is considered as the most successful and difficult weld repair, was carried out on a steam turbine casing which had developed 21 cracks totalling approximately $508 \mathrm{~cm}$ in length (Yosh \& Captoon 1992). The failure was due to a combination of low cycle fatigue and creep. After excessive trials on weldability establishment, carbon equivalent consideration, possible distortion and necessary heat treatments, the repair was carried out on a $1 \mathrm{Cr}-1 \mathrm{Mo}-1 / 4 \mathrm{~V}$ material with a preheat of $343 \pm 27^{\circ} \mathrm{C}$ using AWS 8018 B2L iron powder, low hydrogen electrodes with sufficient clampings to prevent distortion and sufficient padding to maintain adequate preheat. The job is reported to be functioning satisfactorily since 1987 .

Perhaps the most striking example of the effect of inappropriate weld repair procedures was the explosion at the Union Oil Refinery near Chicago in 1984 which caused the deaths of 17 people (McHenry et al 1986). The failure was associated with a circumferential weld used to join a replacement section in a manoethanalomine contactor vessel to the original shell. The replacement was necessary due to the extensive damage to the original casing caused by HIC. All materials were A516 Gr.70. The vessel was originally fabricated using submerged arc welding with very high heat input, which led to low HAZ hardness values. The repair weld done in the field in the $2 \mathrm{G}$ position had to be made using SMAW electrodes at a much lower heat input. This inevitably led to much higher hardness levels in the repair weld HAZ such that, during service, hydrogen from the process entered the steel and initiated cracking in the hardened HAZ. This crack propagated in a mechanism similar to hydrogen induced cracking until full penetration of the vessel wall was reached and then a catastropic fast fracture ensued.

Another example is a decision made not to repair a crack in view of the possible differences in toughness in the case of North Caramount Jacket failure (Harrison 1981). The original welds were made by SAW process and had excellent toughness. At a late stage of the fabrication of the jacket, cracks were discovered in the longitudinal seams of the tubular members forming the legs of the structure. Repairs were considered but trials carried out prior to repair indicated that manual welding repair will have much lower toughness than the original welds. This factor led to the decision not to repair the pre-existing discontinuities in the seam welds. 
Weld joints are particularly tolerant to some types of discontinuity and fracture mechanics techniques are now available which allow rational decisions on the significance of weld discontinuities to be made. If these techniques are more widely applied, the number of weld repairs carried out could be reduced significantly.

\section{Conclusion}

Weld failures and their repairs affect the productivity and safety of any industrial organisation. While weld failures that occur during fabrication can be repaired rather easily, those that occur during service pose serious problems during repair. Inaccessibility of the area, inability to use the shop practices with appropriate preheat and post-weld heat treatments and lack of adequate data on the previous history of the components are some of the problems. Hence, during welding of carbon steels, low alloy high strength or stainless steels, adequate data on the weldability of the material including carbon equivalent, hydrogen induced cracking, solidification cracking, lamellar tearing etc. should be established. Several testing methods are available to evaluate the cracking susceptibility. In addition, fracture mechanics and fitness-forpurpose criteria should be adopted and an appropriate weld repair technique can be judiciously selected.

The author wishes to thank the management of the Bharat Heavy Electricals Limited for all their encouragement.

\section{References}

Alexander L K 1981 Norges Offentlige Utredning (Oslo: University Press) p. 11

Bailey N 1978 Effect of wire composition and flux type on solidification cracking when submerged arc welding C-Mn steels. Weld. Res. Int. 8: 215-239

Baker R G, Watkinson F, Newmann R P 1966 Proc. of 2nd Commonwealth Welding Conf. (London: The Welding Inst.) pp 125-131

Boniszewski T, Watkinson F 1964 Examination of hot tearing in the weld heat affected-zone of ferritic steels. Br. Weld. J. 11: 610-619

Castner H R 1993 What you should know about austenitic stainless steels. Weld. J. (Miami) 72: $53-60$

Christensen N, Simonsen T 1981 Assessment of weldability by the implant method. Scand. $J$. Metal. 10:120-126

Dearden J, O'Neil H 1940 A guide to the selection and welding of low alloy structural steels. Trans. Inst. Weld. 3: 203-214

de Meester B 1991 Selection of steels according to their charpy-V properties in order to avoid brittle fracture. Indian Weld. J. 23: 26-30

Dhooge A, Vinckier A 1992 Reheat cracking - Review of recent studies. Weld. World 30: 44-71

Dixon B 1983 Tests for weldmetal solidification cracking-A Review. Aust. Weld. J. 28: 16-22

Doty W D 1970 in Weldability of structural and pressure vessel steels. Conf. Proc. (London: The Welding Inst.) 1: 163-176

Evans G M, Christensen N 1971 Correlation of weld metal hydrogen content with HAZ embrittlement. Metal Constr. Br. Weld. J. 3: 188-189

Farrar J C M, Dolby R E, Baker R G 1969 Lamellar tearing in welded structural steels. Weld. J. Res. 48 (Suppl.): $274 \mathrm{~s}-282 \mathrm{~s}$ 
Farrar J C M, Garland J G 1973 The Welding Inst. Res. Rep. M/77/73

Granjon H 1960 Rev. Met. 57: 319

Granjon H 1969 The implant method for studying the weldability of high strength steels. Metal Constr. Br. Weld. J. 1: 509-515

Harrison J D 1981 The economics of a fitness-for-purpose approach to weld defect acceptance. In Fitness-for-purpose validation of welded construction (London: The Welding Inst.)

Hemsworth B, Boniszewski T, Eaton N F 1969 Classification and definition of high temperature welding cracks in alloys. Metal Constr. Br. Weld. J. 1:5-16

Konishchev B P, Yakuskin B F, Polymin G E 1977 Svar. Proizvad 24: 12-13

Kotecki D J 1992 Hydrogen reconsidered. Weld. J. (Miami) 71: 35-43

Kula E B, Anetil A A 1977 In Case studies in fracture mechanics, AMMRC report

Lin W, Lippold J C, Baeslack W A III An evaluation of heat-affected zone liquation cracking susceptibility Part 1, Development of a method for quantification. Weld.J. Res. 72 (Suppl.): $135 \mathrm{~s}-153 \mathrm{~s}$

Lundin C D, Khan K K 1990 WRC Progress Report

McHenry H I, Shives T R, Read D T, McColskey J D, Brady C H, Purtscher P T 1986 Examination of a pressure vessel that ruptured at the Chicago refinery of the Union Oil Company on July 23, 1984, NBS Report, NBSIR 86-3049

McKeown D 1970 Versatile weld metal cracking tests Metal Constr. Br. Weld. J. 2: 351-352

McParlan M, Graville B A 1976 Hydrogen cracking in weld metals. Weld. J. Res. 55 (Suppl.): $94 \mathrm{~s}-102 \mathrm{~s}$

Meitzner C F, Stout R D 1966 Microcracking and delayed cracking in welded, quenched and tempered steels. Weld. J. Res. 55 (Suppl.): 393s - 400s

Nakagawa H, Hamanaka T, Matsuda F, Senda T 1975 Weld solidification crack susceptibility of high tensile low nickel alloy steel (Report 6). Trans. Jpn. Weld. Soc. 6: 10-16

Povezan J 1978 Restraint intensity - a significant factor for evaluation of cold cracking of the welds. Weld. News, 2: 31-45

Rawlings G N, Wilken K 1992 Comparing the effectiveness of new hot cracking test methods. Schweissen Schneiden 44: E75-E78

Rosenfield A R, Reid C N 1977 In 'Case Studies in Fracture Mechanics', AMMRC report

Satoh K, Matsui M 1968 Reaction stress and weld cracking under hindered constructions, IIW/IIS doc. No. IX-574/68

Savage W F, Lundin C D 1965 The varestraint test. Weld. J. Res. 44 (Suppl.): 433s 442 s

Savage W F, Nippes E F, Goodman G M 1977 Effect of minor elements on hot-cracking tendencies of Inconel 600, Weld. J. Res. 56 (Suppl.): 243s-245s

Veeraraghavan R, Raghupathy V P, Chandrasekharaiah M N 1988 Weldability evaluation of structural steels- $A$ new perspective (Vishakhapatnam: Indian Inst. Weld.)

Widgery D J 1971 Welding Institute Report

Wilken K, Schoenherr W 1975 Description of four hot cracking tests without self-restraint. Weld. World 13: 238-249

Yosh D, Captoon A 1992 Successful welding repair of turbine casing cracks. Weld. J. 71: 29-32 